\title{
Body Mass Index Less Than 19
}

National Cancer Institute

\section{Source}

National Cancer Institute. Body Mass Index Less Than 19. NCI Thesaurus. Code C138932.

Indicates a body mass index measurement less than 19. 